\title{
Studying the Source Material for Yellow Melilot Selection
}

\author{
Nina Chukhlebova, Inna Donets*, Anna Golub, and Olga Mukhina \\ Stavropol State Agrarian University, Stavropol, Russia
}

\begin{abstract}
Creation of a system that ensures stable and complete feeding of farm animals is important for an effective development of animal husbandry in Stavropol Territory. Science established and practice confirmed that to organize healthy functioning of animals and their high productivity, it is necessary to have at least $105-110 \mathrm{~g}$ of digestible protein per feed unit. However, due to the current use of feed mainly consisting of cereals, there is a deficiency of protein, which is balanced by fodder grains. The lack of protein and its quality in feed has an extremely negative effect on the health of animals, reduces their productivity, impairs reproduction, disrupts metabolism and leads to overspending of feed, and, consequently, to an increase in the cost of livestock products. For the effective use of saline soils, which in the Stavropol Territory account for $24.8 \%$ of the total area, it is necessary to select field crops that give high yields of fodder rich in digestible protein, as well as to improve the structure of saline soils by enriching them with ecologically clean nitrogen that does not cause acidification. The legume crop of yellow melilot can become such a crop. Solving the problem of organic farming, it is necessary to expand the assortment of yellow melilot to create a solid fodder base, to use it as the best forecrop and break crop in grain crop rotations. Therefore, the study of some collection material of yellow melilot on leached black soils and the selection of promising samples is relevant for further selection work to create new varieties. A study of the seed material samples of yellow melilot from the VIR collection of different geographical origins was carried out according to the presence of hard seeds; samples with low and high content of them were established. The sowing qualities of yellow melilot collection samples were studied in laboratory conditions. The growth dynamics of the yellow melilot samples was studied, and decades of the maximum daily growth of yellow melilot were established. A high yield of yellow melilot samples in the first and second year of life was shown. The quantitative composition of main nutrients in the fodder mass of the yellow melilot samples of different geographical origins was established. For the conditions of the Stavropol Territory, it is necessary to select samples with economically valuable biological characteristics that can provide high rates of linear growth of green mass before the onset of summer drought.
\end{abstract}

\footnotetext{
${ }^{*}$ Corresponding author: Donets.Inna.stav@mail.ru
} 


\section{Introduction}

The Stavropol Territory is characterized by the presence of a significant amount of saline soils, there are more than 1180 thousand hectares and about 770 thousand hectares of land are subject to salinization, this comes to $24.8 \%$ of the total area of the region [1]. Such soils were formed on Maykop clays characterized by salinity and alkalinity. According to the soil survey data from Stavropol NIIgiprozem and Stavropol SAU, there is a great variety of humus content in the plow-layer of such soils, its amount ranges from 4.52 to $7.08 \%$ at a $\mathrm{pH}$ of 6.6 to 8.2. The total nitrogen content in the arable layer reaches $0.196-0.238 \%$ [2].

The legume crop of yellow melilot that differs from other legumes of perennial grasses in salt tolerance to chloride salinization can improve physical properties of saline soils [3].

Melilot is promising for use as a break crop, especially in the zone of sufficient and unstable moisture of the Stavropol Territory, where the area under complete fallow is 900 thousand hectares, instead of 600 thousand hectares according to the scientifically grounded farming system. It is advisable to use complete fallow in extremely arid and arid zones of the region [4].

The most important food crop in the Stavropol Territory is winter wheat, which is resown on an area of over 6,000 hectares. Some farms sow winter wheat for three years; in order to change the current situation, it is necessary to select good forecrops.

Melilot, which can enrich the soil with organic substances, accumulating them up to 5-7 t/ha can become such a forecrop in crop rotation. A powerful root system, penetrating to great depths, improves soil aeration, its physical properties, enriches it with ecologically clean easily assimilated bound nitrogen [5; 8].

Yellow melilot as a fodder crop in various regions of Russia forms high yields of green mass and hay that are rich in protein and essential nutrients [6].

Formation of stable yields of green and dry mass of yellow melilot is greatly influenced by the seed material quality, the amount of hard seeds or stony seeds.

Solving the problem of organic farming, it is necessary to expand the assortment of yellow melilot to create a solid fodder base, and also to use it as the best forecrop and break crop in grain crop rotations.

The study of some collection material of yellow melilot on leached black soils and the selection of promising samples are relevant for further selection work to create new varieties.

\section{Research methodology}

The studies to identify promising for selection and production yellow melilot samples were carried out in the experimental station of the Stavropol State Agrarian University [7].

The biennial yellow melilot samples - Melilotus officinalis (L.) Pall. of various geographical origins, selected from the collection of the Vavilov All-Union Institute of Plant Industry (St. Petersburg) served as research material.

The research program provided for the study of economic and biological characteristics of 32 samples of VIR collection of the biennial yellow melilot in the specific climatic conditions of the Stavropol Territory on leached black soils.

The study of the biennial yellow melilot collection was carried out in non-irrigated conditions according to 1979 VIR method [9]. Cluster sowing - 70 x $30 \mathrm{~cm}, 5-7$ seeds per hole followed by a thinning out to one plant. Plot area $-4.2 \mathrm{~m}^{2}$, in four replicates. The Alsheevsky standard variety was sown every 10 rows. The collection was systematically arranged in two tiers.

The experimental site soils were characterized by the following agrochemical indicators: the content of easily hydrolyzable nitrogen in the plough-layer was low - $8 \ldots 15$ 
mg, the reserves of gross phosphorus were significant, but there was little available (mobile) phosphorus - 14-16 mg, due to the presence of a large amount of carbonates in the soil, which convert phosphorus into forms not easily soluble for plants (tricalcium phosphorus). The supply of potassium was good - $292 \ldots 336 \mathrm{mg}$ per $1 \mathrm{~kg}$ of soil.

\section{Research results}

The economic efficiency of the melilot culture largely depends on the use of high quality seeds for sowing, with a low content of hard or stony seeds and high sowing qualities. To identify samples of melilot with a minimum amount of hard seeds in laboratory conditions, experiments were carried out on germinating the sample seeds in an aqueous medium without scarification. The received results are shown in Table 1. The studies established that the number of hard seeds of the studied samples of melilot was in the range of $41.8 \ldots$ 87.8\%. Their minimum amount was formed in the sample from the USA (k-36680) 41.8\%. The maximum amount of hard seeds was found in samples from Stavropol (k38047) - 87.8\%, as well as from the USA (k-36673, Kazakh SSR (k-35312) having 80.0\% of hard seeds).

Seeding of melilot with a high content of hard seeds without scarification leads to a decrease in sowing qualities, the germination energy and germination capacity are, respectively, $8 . . .24 \%$ and $10.0 \ldots 42.8 \%$. In the option with scarification, the numbers were, respectively, $24.0 \ldots 96.0$ and $60.0 . .96 .3 \%$. The sample from the USA (k-36680) was distinguished by high indicators of seed quality and contained a minimum amount of hard seeds $-41.8 \%$ and germination energy equal to $96.0 \%$.

Table 1. Seed sowing qualities of yellow melilot samples (average according to 2 trial establishments)

\begin{tabular}{|c|c|c|c|c|c|}
\hline $\begin{array}{c}\text { Sample } \\
\text { number } \\
\text { according to } \\
\text { VIR catalog }\end{array}$ & Origin & $\begin{array}{c}\text { Weight of } \\
1000 \\
\text { seeds, g }\end{array}$ & $\begin{array}{c}\text { Hard seed } \\
\text { content without } \\
\text { scarification, \% }\end{array}$ & $\begin{array}{c}\text { After scarification } \\
\text { energy, \% }\end{array}$ & $\begin{array}{c}\text { Germination } \\
\text { rate, \% }\end{array}$ \\
\hline $\begin{array}{c}\text { Alsheevsky } \\
\text { (standard) }\end{array}$ & Bashkir ASSR & 1.57 & 64.0 & 56.0 & 84.0 \\
\hline K-13294 & $\begin{array}{c}\text { Astrakhan } \\
\text { region }\end{array}$ & 1.21 & 68.2 & 72.0 & 80.0 \\
\hline K- 38925 & USA & 1.87 & 61.4 & 24.0 & 84.0 \\
\hline K-10368 & $\begin{array}{c}\text { Krasnodar } \\
\text { Krai }\end{array}$ & 1.51 & 74.6 & 68.0 & 68.0 \\
\hline K- 36680 & USA & 2.75 & 41.8 & 96.0 & 96.0 \\
\hline K- 39362 & Novosibirsk & 1.45 & 75.4 & 84.0 & 88.0 \\
\hline
\end{tabular}

The study of melilot growth dynamics made it possible to identify the samples that are most adapted to the conditions of the Stavropol Territory. In the first year of life, melilot is characterized by slow growth rates during the first 35-48 days of ontogenesis; the daily increase in plant height during this period averaged $0.3-0.7 \mathrm{~cm}$ over two years, during this period the aboveground mass slows down the daily gain using products of photosynthesis for the root system formation. In the first year of melilot's life, a high rate of daily growth was observed in the period from the $2^{\text {nd }}$ decade of May to the $2^{\text {nd }}$ decade of August and amounted to $1.1 \ldots 2.3 \mathrm{~cm}$. Samples from the USA were distinguished by high growth rates of vegetative shoots (k-36680, k -38925, k-36679).

In the second year of life, the melilot samples differed greatly. Within 30-45 days after the beginning of spring regrowth, the daily growth was within $0.5 \ldots 1.2 \mathrm{~cm}$. The maximum daily growth of the best samples fell on the $2^{\text {nd }}$ and $3^{\text {rd }}$ decade of May and was $2.1-3.5 \mathrm{~cm}$, 
which was 1.9 times more than the standard. The peak growth of $3.5 \mathrm{~cm}$ was observed in the sample k -36680 in the 'branching-budding' interfacial period. For the Stavropol Territory conditions, it is necessary to select samples with economically valuable biological characteristics that can provide high rates of linear growth of green mass before the onset of summer drought.

Mid-season and late-season yellow melilot samples reach maximum growth in the $2^{\text {nd }}$ half of summer, during the period of the most probable moisture deficit. Early-season melilot samples release the field early after harvesting, this enables one to prepare the soil for sowing winter wheat, which is important in the structure of the farm's crop rotation.

In the first year of life, most of melilot samples were characterized by low productivity of fodder mass and instability of its formation over the years of research. The best samples in terms of productivity are shown in Table 2. Accumulation of the melilot fodder mass depends on the amount of precipitation during the period of the most active growth. On average for two years, the yield of green mass of the best samples in the first year of life was in the range of 13.38...17.04 t/ha and exceeded the standard by $2.86 . . .6 .08 \mathrm{t} / \mathrm{ha}$ with the Least Significant Difference $05=4.6$ t/ha.

Table 2. Green mass productivity of isolated samples of yellow melilot, t/ha (average over two years)

\begin{tabular}{|c|c|c|c|c|c|c|c|}
\hline $\begin{array}{c}\text { Sample } \\
\text { number } \\
\text { according to } \\
\text { VIR catalog }\end{array}$ & Origin & $\begin{array}{c}\text { First } \\
\text { year of } \\
\text { life }\end{array}$ & $\begin{array}{c}\% \\
\text { to the } \\
\text { standard }\end{array}$ & $\begin{array}{c}\text { Second } \\
\text { year of } \\
\text { life }\end{array}$ & $\begin{array}{c}\% \\
\text { to the } \\
\text { standar } \\
\mathrm{d}\end{array}$ & $\begin{array}{c}\text { Amoun } \\
\mathrm{t} \\
\text { in } \\
\text { two } \\
\text { years }\end{array}$ & $\begin{array}{c}\% \\
\text { to the } \\
\text { standar } \\
\mathrm{d}\end{array}$ \\
\hline $\begin{array}{c}\text { Alsheevsky } \\
\text { (standard) }\end{array}$ & Bashkir ASSR & 10.96 & 100.0 & 25.21 & 100.0 & 36.17 & 100.0 \\
\hline K-13294 & Astrakhan region & 13.52 & 123.4 & 29.05 & 115.2 & 42.57 & 117.7 \\
\hline K- 38925 & USA & 16.69 & 152.3 & 31.78 & 123.1 & 48.47 & 134.0 \\
\hline K-32834 & Canada & 13.38 & 123.0 & 32.40 & 128.5 & 45.78 & 126.6 \\
\hline K-36680 & USA & 17.04 & 171.4 & 41.71 & 165.0 & 58.75 & 162.4 \\
\hline $\begin{array}{c}\text { K-36679 } \\
\text { USA }\end{array}$ & 16.79 & 153.2 & 38.34 & 152.1 & 55.13 & 152.4 \\
\hline $\begin{array}{c}\text { Least } \\
\text { Significant } \\
\text { Difference } \\
05\end{array}$ & - & 4.6 & - & 2.3 & - & 6.1 & - \\
t/ha & & & & & & & \\
\hline
\end{tabular}

In the second year of life, the yield was 29.05...41.71 and exceeded the standard by 3.84...16.50 t/ha with Least Significant Difference $05=2.3 \mathrm{t} / \mathrm{ha}$. In total over two years the yield of green mass of isolated samples exceeded the standard by 17.7...62.4\%. The increase in melilot harvest in the first year of life was $23.0 \ldots 71.0 \%$, in the second year 15.2...65.0\%.

The best in terms of green mass yield turned out to be samples from the USA (k36680 and $k-36679$ ), which are of selection interest.

The use of melilot for animal feed requires an assessment of the fodder mass for the basic nutrient content. Studies have shown that melilot in terms of the basic element content is close to clover and alfalfa, and that removed in the 'budding-beginning of flowering' phase contains the maximum amount of crude protein (Table 3.). 
Table 3. Basic nutrient content in the fodder mass of yellow melilot, (average over two years)

\begin{tabular}{|c|c|c|c|c|c|}
\hline \multirow{2}{*}{$\begin{array}{c}\text { Sample number } \\
\text { according to VIR } \\
\text { catalog }\end{array}$} & \multirow{2}{*}{ Origin } & \multicolumn{2}{|c|}{ Food compounds, \% } & $\begin{array}{c}\text { Crude } \\
\text { protein, } \\
\mathbf{\%}\end{array}$ \\
\cline { 3 - 6 } & Bashkir ASSR & 3.26 & 0.63 & 1.54 & 20.37 \\
\hline $\begin{array}{c}\text { Alsheevsky } \\
\text { (standard) }\end{array}$ & Astrakhan region & 3.24 & 0.77 & 1.88 & 20.25 \\
\hline K-13294 & USA & 3.22 & 0.70 & 1.58 & 20.12 \\
\hline K- 38925 & USA & 3.48 & 0.72 & 1.78 & 21.75 \\
\hline K- 36680 & Canada & 3.47 & 0.67 & 1.79 & 21.69 \\
\hline K-32834 & USA & 3.46 & 0.79 & 1.76 & 21.62 \\
\hline K-36679 & \multicolumn{2}{|l}{} \\
\hline
\end{tabular}

The crude protein content in the air-dry mass of melilot was in the range of 20.37...21.75\%.

Samples from the USA k-36680 and k-36679 had high amounts of crude protein, as well as a sample from Canada k-32834. These samples were distinguished by a high accumulation of nitrogen in the feed mass. The data on phosphorus accumulation in the fodder mass of melilot differ by region, for example, in Yakutia the phosphorus content is very low - 0.14...0.34 [10]. In our experiments, the separated samples have a high phosphorus content from 0.63 to $0.79 \%$, which exceeds the standard by $0.04 \ldots 0.16 \%$. The potassium content in the samples under study is from 1.58 to $1.88 \%$, which is $0.04 \ldots 0.34 \%$ higher than the standard.

\section{Conclusion}

The number of hard seeds of the studied melilot samples is in the range of $41.8 \ldots 87.8 \%$. Their minimum number is formed in the sample from the USA (k-36680) - 41.8\%. The maximum amount of hard seeds was found in the samples from Stavropol (k-38047) 87.8\%, as well as from the USA (k-36673), Kazakh SSR (k-35312) having 80.0\% of hard seeds.

The sample from the USA (k-36680) was distinguished by high indicators of seed quality, contained the minimum amount of hard seeds $-41.8 \%$ and its germination energy was equal to $96.0 \%$.

The maximum daily growth in the first year of life was observed in the period from the $2^{\text {nd }}$ decade of May to the $2^{\text {nd }}$ decade of August and amounted to $1.1 \ldots 2.3 \mathrm{~cm}$. Samples from the USA (k-36680, k-38925, k -36679) were distinguished by high growth rates.

The maximum daily growth in the second year of life of the best samples falls on the $2^{\text {nd }}$ and $3^{\text {rd }}$ decade of May and is $2.1-3.5 \mathrm{~cm}$, which is 1.9 times more than the standard. The peak growth of $3.5 \mathrm{~cm}$ is observed in the sample k-36680 in the 'branching-budding' interfacial period. For economic use in the Stavropol Territory, the most acceptable samples are those with high growth rates in May-June, capable of forming a crop of green mass before the onset of the summer drought.

The yield of green mass of the best samples in the first year of life was in the range of 13.38...17.04 t/ha and exceeded the standard by 2.86...6.08 t/ha with Least Significant Difference $05=4.6 \mathrm{t} / \mathrm{ha}$.

In the second year of life, the yield was 29.05...41.71 and exceeded the standard by 3.84... 16.50 t/ha with Least Significant Difference $05=2.3 \mathrm{t} / \mathrm{ha}$. In total, over two years the yield of green mass of the isolated samples exceeded the standard by 17.7...62.4\%.

The isolated samples of yellow melilot have a high protein content. The air-dry mass contains $20.37 . .21 .75 \%$ of crude protein, from 0.63 to $0.79 \%$ of phosphorus, and this 
exceeds the standard by $0.04 \ldots 0.16 \%$. The potassium content in the samples under study is from 1.58 to $1.88 \%$, which is $0.04 . .0 .34 \%$ higher than the standard.

Early-season samples from the USA (k-36680, k-36679) are promising for further selection work.

\section{References}

1. Chumakova V.V., Sheikina V.A. Influence of sodium chloride solutions on sowing qualities of yellow melilot // In collection of works Agricultural Science, Creativity and Growth: International Scientific and Practical Conference Volume II. 2015. Stavropol: SEKVOYA. pp. 248-250.

2. Tskhavrebov V.S., Faizova V.I., Kalugin D.V., Nikiforova A.M. Global changes in the soil-forming process in the conditions of agrophytocenoses // Proceedings of the Institute of Geology of the Dagestan Scientific Center of the Russian Academy of Sciences. 2012- No. 61. pp. 134-137.

3. Chukhlebova N.S., Golub A.S., Shabaldas O.G., Belovolova A.A. Effect of infusions of plant crops on the quality seed yellow sweet cloverr. Research Journal of Pharmaceutical, Biological and Chemical Sciences. 2016. Vol. 7. No. 3. pp. 2560-2564.

4. Penchukov V.M., Dorozhko G.R., Perederieva V.M. et al. Problems of biologization of agriculture in the agro-industrial complex of the Stavropol Territory // State and prospects for the development of the agro-industrial complex of the North Caucasian Federal District. Mater. $74^{\text {th }}$ Scientific and Practical Conference. - Stavropol: Paragraph Stavropol Publ., 2010. pp. 107-111.

5. Shabaldas O.G., Golub A.S., Zelenskaya T.G., Donets I.A., Mukhina O.V. Symbiotic activity and productivity of soybean, depending on the methods of presowing treatment of soybean seeds in the conditions of central ciscaucasia Research Journal of Pharmaceutical, Biological and Chemical Sciences. 2018. Vol. 9. No. 4. pp. 688-691.

6. Volodin A.B., Donets I.A., Golub A.S., Chukhlebova N.S., Kapustin A.S. Use of cytoplasmic male sterility in the selection of sorghum. Research Journal of Pharmaceutical, Biological and Chemical Sciences. 2018. Vol. 9. No. 6. pp. 15621565.

7. Chukhlebova N.S., Donets I.A., Golub A.S. Method of obtaining original material for the selection of yellow melilot under the conditions of the Stavropol Territory. IOP Conference Series: Earth and Environmental Science Krasnoyarsk Science and Technology City Hall of the Russian Union of Scientific and Engineering Associations. 2019. 42004 p.

8. Danilets E.A., Vlasova O.I. Influence of the links of the field crop rotation on the biological factors of soil fertility // News of the Nizhnevolzhsky agro-university complex: Science and higher professional education. 2019. No. 3 (55). pp. 184-191.

9. Guidelines for studying the collection of perennial forage grasses. L. VIR. 1979. 39 p.

10. Yakovlev A.S. Donnik (Melilotus) - A promising forage crop in Central Yakutia // Tr. Yakut. NPPA. 1970. Issue 10, pp. 149-162. 